\title{
Vragenlijst B
}

1. Wat is uw geslacht?
- Man
- Vrouw
- Anders

2. Wat is uw leeftijd?

3. Wat is de hoogste opleiding die $u$ heeft gedaan?
- geen school
- basisschool
- voortgezet onderwijs (middelbare school)
- hogere schooling (zoals mbo, hbo of universiteit)

4. In welk soort huis verblijft $u$ op dit moment? (meerdere antwoorden mogelijk)

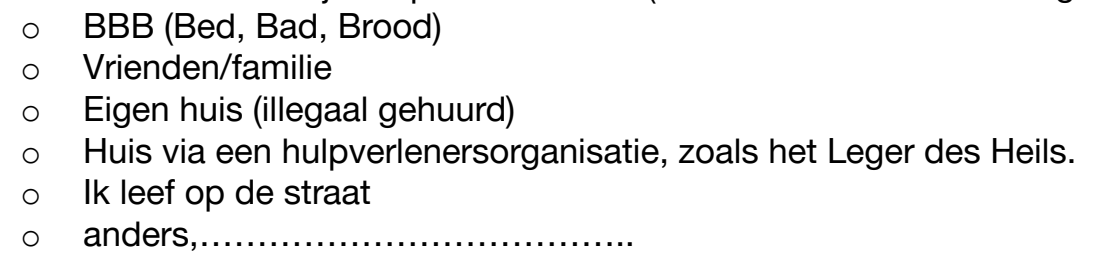

5. Wanneer bent u vertrokken uit uw land van herkomst? jaar: |______

6. Sinds wanneer verblijft $u$ in Nederland? jaar: |_L____

7. Hoe bent u Nederland binnengekomen?

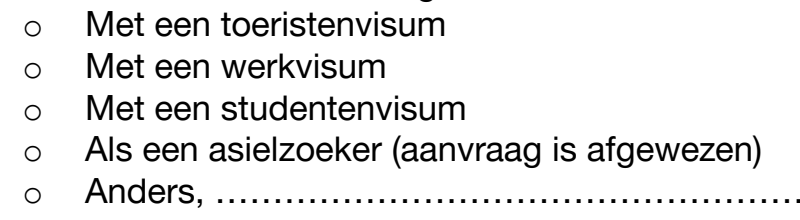

8. Leeft $\mathrm{u}$ op dit moment met andere personen in een huis?

○ Ja, met ..... personen (aantal)

$\circ \quad \mathrm{Nee}$

Indien ja: Met wie woont u samen? (meerdere antwoorden mogelijk!)

$\square \quad \mathrm{lk}$ woon samen met mijn partner

$\square \quad$ Ik leef samen met mijn kinderen onder de 4 jaar

Ik leef samen met mijn kinderen tussen de 4 en 17 jaar

Ik leef samen met mijn kinderen, ouder dan 18 jaar

Ik woon samen met mijn ouders of schoonouders

$\square \quad$ Ik leef met anderen, namelijk

9. Bent $u$ de afgelopen 6 maand voor meer dan 24 uur in het buitenland geweest?

○ Ja, namelijk in de volgende landen:

1).

2).

3)..

- Nee 
